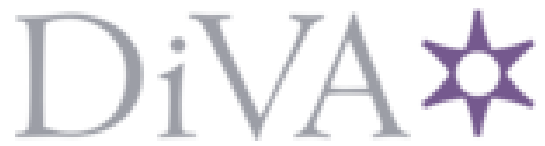

http://www.diva-portal.org

\title{
Postprint
}

This is the accepted version of a paper published in . This paper has been peer-reviewed but does not include the final publisher proof-corrections or journal pagination.

Citation for the original published paper (version of record):

Mason, E. (2021)

Is There a (Black) Literature?

Academia Letters

https://doi.org/10.20935/al3805

Access to the published version may require subscription.

N.B. When citing this work, cite the original published paper.

Permanent link to this version:

http://urn.kb.se/resolve?urn=urn:nbn:se:uu:diva-458149 


\section{Is There a (Black) Literature?}

1.

What exactly is the use of merging the semantics of literature and nation? What is called into being when literature is subsumed into the categorical imperatives of a bordered nation? What is American about American literature? What is African about African-American literature? Is this question questionable at all?

2.

Taxation - and therefore the value-form of capitalism - is in the roots of both the American Revolution and the U.S. Civil War, which is to say that America as America is founded on the refusal of taxation.

In his satirical article 'Rules by Which a Great Empire May Be Reduced to a Small One', Benjamin Franklin critiques the ur-American injustice of being taxed. Addressing himself to Britain, he writes:

reflect that a penny taken from [your colonies] by your power is more honorable to you, than a pound presented by their benevolence; despise therefore their voluntary grants, and resolve to harass them with novel taxes. They will probably complain to your parliaments, that they are taxed by a body in which they have no representative, and that this is contrary to common right. They will petition for redress. Let the Parliaments flout their claims, reject their petitions, refuse even to suffer the reading of them, and treat the petitioners with the utmost contempt. Nothing can have a better effect in producing the alienation 
proposed; for though many can forgive injuries, none ever forgave contempt. ${ }^{1}$

Marx writes that "every form of production creates its own legal relations, form of government, etc." 2 Production is a complex relational movement that establishes the social context and content of its generated society. In America, the economy of slavery produces a country bound to the originary proposition of two entangled abstractions: race and value. Value as the exchange form of capital that accumulates through free circulation is given its freedom through the originary American act of resisting taxation. The socially cohesive proposition of nationwide taxation, its regulation and its distribution, is precisely the form of government against which the form of production of America distinguishes itself.

America here appears as a deeply arbitrary system of signs that must endlessly enforce America's own impossibility. The slave is the foundational generative site of valuereproduction in/as America, and yet is constantly eluded in the founding documents, and later counts explicitly as three-fifths of a person for the purposes of the master's political representation. ${ }^{3}$ The accumulation of autonomous capital as the nation was the dogma of the revolutionaries, who wanted surplus to remain inside the borders; meanwhile America is the expansive force of global finance capital, the paradigm of the neoliberal redeemer of the freedom of value, defining itself by the refusal to enclose capital in any state-enforced limitations.

\footnotetext{
${ }^{1}$ Benjamin Franklin, 'Rules by Which a Great Empire May Be Reduced to a Small One' (1773), 451-456, Robert S. Levine, The Norton Anthology of American Literature, Ninth Edition (New York, NY: W. W. Norton \& Company, 2016), 452-453.

${ }^{2}$ Karl Marx, Grundrisse, trans. Martin Nicolaus (London: Penguin, 1973 [1939]), 21.

${ }^{3}$ Slave/slavery is never stated in any of the founding documents. The "three-fifths" clause produces a mathematical catachresis of slavery (1.2.3), also signalling the abstraction of "other Persons" (1.2.3), while elsewhere reference is made to "such Persons" (1.9.1) and "No Person held to Service or Labour" (4.2.3).
} 


\section{3.}

In Blackness and Value, Lindon Barret asks how "an interrogation of value as an abstract principle" can open more complex questions about the central importance of race in the American economy and culture. He begins,

in U.S. cultural logic the abstract entities 'value' and 'race' keenly reflect one another, even to a point at which they might be considered isomorphic. At its simplest, value is a configuration of privilege, and, at its crudest, race is the same. Insofar as value, as a theoretical dynamic, promotes one form(ation) to the detriment of another (or others), race proves a dramatic instantiation of this principle. $^{4}$

These isomorphic violences are distributed in three stages. The first is the "force of value", which is imposed as a universal standard of worthiness of life in its most essential appearance. The second is the "form of value", which regulates the appearance of temporal advancement or lag, racializing claims of civility and technological development, while demarcating the boundaries of who is intellectually capable of the production of valuable culture. The form of value is the praxis of centring certain pseudoscientific signs (principally Whiteness, but also Christianity, heteronormativity, masculinity, ability, nationality, etc.) as the generative regulator of backwards or problematic signs. The third is the "denial of value", in which the form of value exerts itself as the act of covering its initial and originary act of violence by which it imposed itself as the universal standard of valuation.

In short, value is a self-concealing relation that disguises its own generative centrality to the normative operation of existing in capitalist modernity; denial is the continuous and

\footnotetext{
${ }^{4}$ Lindon Barrett, Blackness and Value: Seeing Double (Cambridge: Cambridge University Press, 1999), 1-2.
} 
fundamental practice of the violence of American culture: cultural productions can only be coded as American if they deny the violence that promotes the originary declaration-asAmerica of value and race, which is to say of the refusal of taxation and the afterlives of slavery.

\section{4.}

In What Was African American Literature? Kenneth Warren proceeds from the understanding that "the mere existence of literary texts does not necessarily indicate the existence of a literature", importantly destabilizing the appearance of written texts necessarily cohering as a unified national practice. For Warren, African American literature refers to a writing practice directed at a particular audience between the end of the Civil War in 1865, which began the Jim Crow era ${ }^{6}$ and the 1965 Voting Rights Act, which formally ended a century of Jim Crow laws. The conditions of Jim Crow were the setting for a specific form of cultural response among Black Americans, cohering as African American literature, which, as Warren writes, "constitute[d] a representational and rhetorical strategy within the domain of a literary practice responsive to conditions that, by and large, no longer obtain."7

Warren is certainly under no illusion that currently racism is any less prevalent or powerful than before 1965, but the conditions are wholly different, giving the imperative of cultural productions a different form of coherence and a different relation to its audience. The shift between the Jim Crow era of African American literature and whatever has succeeded it is signalled, Warren writes, by “changes in preferred nomenclature, from 'colored' and 'Negro' to 'black' and 'African American'.," These changes remove the direct link from the conditions

\footnotetext{
${ }^{5}$ Kenneth W. Warren, What Was African American Literature? (Cambridge, MA: Harvard University Press, 2011), 6 .

${ }^{6}$ This gained more specific African American significance for cultural productions after the Plessy v. Ferguson trial of 1896, which upheld and publicized the "separate but equal" doctrine.

${ }^{7}$ Warren, What Was African American Literature? 9.

${ }^{8}$ Ibid., 5.
} 
immediately following slavery to the conditions following the Civil Rights era, which is not to say that there is no semantic continuation in these cultural productions, but rather that to see African American literature as a singular and uniform pursuit over two and a half centuries is to vastly underestimate the complexity of the arbitrary system of signs and the separate but isomorphic processes of violence through which America endlessly reenacts its selfdeclaration into being.

As Henry Louis Gates Jr. writes, "the Afro American literary tradition was generated as a response to eighteenth- and nineteenth-century allegations that persons of African descent did not, and could not, create literature." 9 The accusations that perpetuate the originary condition of racialization that is America - the duet of value and race — shifted during the 1960s and onwards, suspending the segregation of education and subsuming Black radicalism and Black literary practices into the university, museums, and other normative mechanisms of capitalist regulation. This shift towards formal inclusion is no less violent than the previous iteration of explicit exclusion, but it is distinct and cannot be understood as being involved in the same coherent national practice as previous productions that understood themselves as African American literature.

5.

There is an Amiri Baraka. There is an Angela Davis. There is a June Jordan. There is a Cedric Robinson. There is a James Baldwin. There is a Toni Morrison. There is an H. Rap Brown. And the fact of the existence of these (post-)Civil Rights Black radicals, and their distinction from a previous generation of Black American writers, opens the impossibility of a singular

\footnotetext{
${ }^{9}$ Henry Louis Gates Jr., Figures in Black: Words, Signs, and the "Racial” Self (New York, NY: Oxford University Press, 1987), 25.
} 
and unifying pursuit of a national/racial literature that coherently responds to the accusation of its impossibility: having become possible in the official distribution of American value, African American literature as a literature is no longer possible.

Most of these late twentieth-century writers worked in universities, and were (or are) paid by those paradigmatic imperial machines of epistemological violence to speak and write their radicalism. Removed from the exclusionary ground of a general resistance, these writers' radicalism loses its unifying singularity, which is certainly not to say that it loses its radicalism.

6.

Ruminating on the general impossibility of Phillis Wheatley writing poetry, on the loss of the first poet, June Jordan writes: "A poet is somebody free. A poet is someone at home." ${ }^{10}$ What is the home of a poet who precedes the naming ceremony of the nation into which her poetry is nationalized? What is the home of a poet whose material house is yet to be constructed? What is home for a poet whose poetry begins with the constant questioning of her ability to write? Wheatley exists as the originary impossibility of being a poet, placed on permanent trial for the ongoing faux pas of writing before the boundaries of inscription, of being a poet who precedes the established para-collective of the possibility of writing poetry. How to be, when there is no way of being?

7.

\footnotetext{
${ }^{10}$ June Jordan, 'The Difficult Miracle of Black Poetry in America: Something like a sonnet for Phillis Wheatley', Poetry Foundation (2006 [2002]) < https://www.poetryfoundation.org/articles/68628/the-difficultmiracle-of-black-poetry-in-america>.
} 
African American, for Alexander Weheliye, is a misnomer that attempts to deny the anahistorical, fugitive form of Blackness by the bourgeois demarcation of discreet global spaces that signify temporal progressiveness. ${ }^{11}$ The referents of the sign "Africa" are placed on a global trajectory defined by imperial power which grant itself the power to define through its self-definition as the site of capital-accumulation: where value is (i.e. America) is where time is leading. The designation of African-American is a physical removal of certain Americans from the site of arrival, creating an implicit stasis, in which African-Americans cannot fully become American because the fact of their genealogy of capture renders them always connected to a place that is placeless, to a place where they are not from, to the home that they never had (i.e. Africa).

"African-American literature" can only refer to the writing of a coherent nation without a nation; it can only mean the spatial boundary of a literature written by a group of people who are defined precisely by their lack of a spatial boundary. National literatures presuppose a nation that coheres as the proposition for its every writer. Given that the first demonym (African) signifies a process of capture and forced removal to the second, and the second (American) signifies the individual liberty of not being taken but rather taking for oneself in the economy of individual competition, African-American literature is the limit of the meaning of national literature.

\footnotetext{
${ }^{11}$ Alexander G. Weheliye, Habeas Viscus: Racializing Assemblages, Biopolitics, and Black Feminist Theories of the Human (Durham, NC: Duke University Press, 2014), 30.
} 